\title{
Immunosuppressive Effects of Mesenchymal Stem Cells versus Corticosteroid in Experimental Model of Arthritis
}

\author{
El-denshary ESM ${ }^{1}$, LA Rashed ${ }^{2}$ and M Elhussiny ${ }^{1 *}$
}

${ }^{1}$ Faculty of Pharmacy, Cairo University, Cairo, Egypt

${ }^{2}$ Department of Medical Biochemistry, Unit of Biochemistry and Molecular Biology, Faculty of Medicine, Cairo University, Cairo, Egypt

\begin{abstract}
Objective: The objective of this study was to compare between the efficacies of mesenchymal stem cell (MSC) and betamethasone in the treatment of rheumatoid arthritis.

Material and method: 90 male albino mice were divided equally into 2 models as follows: MSC model, group 1 : saline control group, group 2: Acetic acid, group 3: CIA, group 4: induced arthritis mice that received intravenous injection of MSCs. Betamethasone model, group 1: phosphate buffer saline, group 2: Acetic acid, group 3: betamethasone control, group 4: CIA, group 5: induced arthritis mice that received intraperitoneal injection of betamethasone. Mice arthritis models were assessed by clinical paw edema and $\mathrm{x}$-rays, at the proper time of sacrefaction, tissues were collected and examined using real-time PCR (RT-PCR), synovial tissue was examined for (IL-10) interleukin-10 (TNF- $\alpha$ ), tumor necrosis factor- $\alpha$, (COMP)-Cartilage oligomeric matrix protein, (MMP-3) Matrix metalloproteinase3. While (MDA), (LDH), (GSH), (CAT) and (MPO) were determined using colorimetric kits. In addition detection of serum level of (IgG), (RF), (CRP), (ANA) by enzyme-linked immunosorbent assay (ELISA).Also detection of blood (ESR)
\end{abstract}

Results: Histopathological, paw edema and PCR results showed improvement of the group that received MSC compared to the diseased group and group received betamethasone.

Conclusion: MSC significantly enhance the efficacy of collagen-induced arthritis treatment, which is superior to betamethasone treatment likely through the modulation of the expression of various cytokines.

Keywords: Collagen-induced arthritis; Mesenchymal stem cell; Betamethasone; Rheumatoid arthritis

\section{Introduction}

Mesenchymal stem cells (MSCs) have the capacity to differentiate into various types of tissue cells and contribute to the regeneration of a variety of mesenchymal tissue such as bone, cartilage, muscle, and adipose. They can be induced to terminally differentiate into osteoblasts, chondrocytes, adipocytes, tenocytes, myotubes, neural cells, and hematopoietic-supporting stroma, either in vitro or in vivo [1-3]. The pluripotent characteristics of MSCs make them attractive therapeutic adult stem cells. Some studies have demonstrated the beneficial effects of MSC therapy in vivo in disorders such as myocardial infarction [4], acutely injured liver [5], and acute renal failure [6]. In addition, it has been reported that MSCs can be used to prevent acute graft-versus host disease (GVHD), suggesting that MSCs may also have immunosuppression functions [7].

Rheumatoid arthritis (RA) affects about $1 \%$ of the adult population. It is a chronic, progressive, and inflammatory autoimmune disease characterized clinically by chronic inflammatory destructive polyarthritis [8]. Currently there is not optimal therapy available for RA except systemic immunosuppressant. Based on the evidence of MSC's immunosuppression function in the prevention of GVHD, we hypothesized that MSCs may also possess immunotherapeutic value in the treatment of RA. In this study, we tested this hypothesis in a CIA mouse model through evaluating the effects on RA recovery as well as the expression of inflammation-related cytokines after MSC. Betamethasone can be highly effective in treating joint inflammation, but its systemic application is limited because of a high incidence of serious adverse effects, especially related to long term treatment $[9,10]$. As intravenously administered betamethasone is distributed throughout the whole body and rapidly cleared, high and frequent dosing is necessary to achieve an effective concentration at inflamed target sites. Moreover, the profound physiological activity of betamethasone in many different tissues increases the risk of adverse effects in patients. It is necessary, therefore, to develop a drug delivery system for betamethasone incorporated in particular carriers, with enhanced localization in the target site and sustained drug release $[11,12]$.

This work aims: to detect the possible role of (MSCs) compared to corticosteroid in treating experimental RA.

\section{Preparation of the Animal Model}

\section{Experimental animals}

The study was carried on 90 male white albino mice, of an average weight 30-35 gm. Mice were bred and maintained in an air-conditioned animal house with specific pathogen-free conditions, and were subjected to a 12:12-h daylight/darkness and allowed unlimited access to chow and water. All the ethical protocols for animal treatment were followed and supervised by the animal facilities, Faculty of Medicine, Cairo University. They were divided into 2 models as follow.

Mesenchymal stem cells model: Group 1: $(n=10)$ control group was received $1 \mathrm{ml}$ saline

Group 2: $(\mathrm{n}=10)$ control group was received $(0.1 \mathrm{~N}$ acetic acid at day 0 and day 21 at the base of the tail) [13].

*Corresponding author: M Elhussiny, Faculty of Pharmacy, Cairo University, Cairo, Egypt, E-mail: d_marwa2060@hotmail.com

Received January 15, 2013; Accepted January 25, 2013; Published January 27 2013

Citation: El-denshary ESM, Rashed LA, Elhussiny M (2012) Immunosuppressive Effects of Mesenchymal Stem Cells versus Corticosteroid in Experimental Model of Arthritis. Clin Exp Pharmacol S5:003. doi:10.4172/2161-1459.S5-003

Copyright: (ㄷ 2012 El-denshary ESM, et al. This is an open-access article distributed under the terms of the Creative Commons Attribution License, which permits unrestricted use, distribution, and reproduction in any medium, provided the original author and source are credited. 
Citation: El-denshary ESM, Rashed LA, Elhussiny M (2012) Immunosuppressive Effects of Mesenchymal Stem Cells versus Corticosteroid in Experimental Model of Arthritis. Clin Exp Pharmacol S5:003. doi:10.4172/2161-1459.S5-003

Page 2 of 10

Group 3: $(n=10)$ control group was received (100 $\mu$ g of murine acid-soluble collagen II at the base of the tail at day 0 and 21 as immunization boost dose) [13].

Group4: ( $\mathrm{n}=10)$ was received mesenchymal stem cells (MSCs) by treating CII-immunized white albino mice with an intravenous injection of $100 \mu \mathrm{l}$ of a cell suspension containing $5 \times 10^{6}$ allogeneic MSCs from mice at the moment of the boost (day 21) [14].

Corticosteroid model: Group 1: $(n=10)$ control group was received $1 \mathrm{ml}$ phosphate buffer saline.

Group 2: $(n=10)$ control group was received $(0.1 \mathrm{~N}$ acetic acid at day 0 and day 21 at the base of the tail) [13].

Group 3: $(n=10)$ control group will receive betamethasone in a dose of $0.05 \mathrm{mg} / \mathrm{kg}$ body weight, intraperitoneally daily [15].

Group 4: $(n=10)$ control group was received $(100 \mu \mathrm{g}$ of murine acid-soluble collagen II at the base of the tail at day 0 and 21 as immunization boost dose) [15].

Group 5: $(\mathrm{n}=10)$ was received betamethasone in a dose of $0.1 \mathrm{mg} /$ $\mathrm{kg}$ body weight, intraperitoneally daily after reaching an arthritis score $\geq 2$ till day 25 [15].

\section{Induction and assessment of arthritis}

Male white albino mice were immunized by injecting an emulsion of $100 \mu \mathrm{g}$ of murine acid-soluble Type II collagen (CII) (Sigma) according to [13].

\section{Clinical paw edema and $\mathrm{X}$-ray assessment}

Clinical scoring of paw edema: Paw swelling was assessed by measuring the thickness of the hind-paws using a caliper. The symptom score was assessed using the following system [16] briefly, grade 0: no swelling; grade $1: \geq 0 \cdot 1 \mathrm{~mm}$ increase in paw swelling; grade $2: \geq 0 \cdot 2$ $\mathrm{mm}$ increase in paw swelling; grade 3: extensive swelling $(\geq 0.3 \mathrm{~mm}$ increase in paw swelling); and grade 4 : pronounced swelling $(\geq 0.45$ $\mathrm{mm}$ increase in paw swelling).

X-Ray filming: X-ray films of the knee joints were taken after the treatments. The settings of the $\mathrm{x}$-ray machine and the degree of arthritic changes were scored using a modified [17]. The score ranged from 0 to 4 scales. Radiographs were taken after induction of arthritis, of knee joint for each animal at the end of the experiment.

\section{Preparation of BM-derived mesenchymal stem cells from mice}

Bone marrow was harvested by flushing the tibiae and femurs of 6-week-old male white albino mice with Dulbecco's modified Eagle's medium (DMEM, GIBCO/BRL) supplemented with 10\% fetal bovine serum (GIBCO/BRL). Nucleated cells were isolated with a density gradient [Ficoll/Paque (Pharmacia)] and resuspended in complete culture medium supplemented with $1 \%$ penicillin-streptomycin (GIBCO/BRL). Cells were incubated at $37^{\circ} \mathrm{C}$ in $5 \%$ humidified $\mathrm{CO}_{2}$ for 12-14 days as primary culture or upon formation of large colonies. When large colonies developed (80-90\% confluence), cultures were washed twice with phosphate buffer saline (PBS) and the cells were trypsinized with $0.25 \%$ trypsin in $1 \mathrm{mM}$ EDTA (GIBCO/BRL) for 5 min at $37^{\circ} \mathrm{C}$. After centrifugation, cells were resuspended in serumsupplemented medium and incubated in $50 \mathrm{~cm}^{2}$ culture flask (Falcon). The resulting cultures were referred to as first-passage cultures [18]. MSCs in culture were characterized by their adhesiveness and fusiform shape; Also CD29 \& CD105 were detected by flow cytometry as a surface marker of MSCs [18].

\section{Labeling of MSCs with PKH26}

MSCs were harvested during the 4 th passage and were labeled with $\mathrm{PKH} 26$, which is a red fluorochrome. It has excitation $(551 \mathrm{~nm})$ and emission $(567 \mathrm{~nm}$ ) characteristics compatible with rhodamine or phycoerythrin detection systems. The linkers are physiologically stable and show little to no toxic side-effects on cell systems. Labeled cells retain both biological and proliferating activity, and are ideal for in vitro cell labeling, in vitro proliferation studies and long, in vivo cell tracking. In the current work, MSCs were labeled with PKH26 from Sigma Company (Saint Louis, Missouri USA). Cells were centrifuged and washed twice in serum free medium. Cells were pelleted and suspended in dye solution. Cells were injected intravenously into mice tail vain. After 21 days, joint knee tissue was examined with a fluorescence microscope to detect and trace the cells (Figure 3).

Real-time quantitative analyses for MMP-3, COMP, IL-10, TNF-a gene expression

Total RNA was extracted from knee joint tissue homogenate using RNeasy purification reagent (Qiagen, Valencia, CA). cDNA was generated from $5 \mu \mathrm{g}$ of total RNA extracted with $1 \mu \mathrm{l}(20 \mathrm{pmol})$ antisense primer and $0.8 \mu \mathrm{l}$ superscript AMV reverse transcriptase for $60 \mathrm{~min}$ at $37^{\circ} \mathrm{C}$

The relative abundance of mRNA species was assessed using the SYBR Green method on an ABI prism 7500 sequence detector system (Applied Biosystems, Foster City, CA). PCR primers were designed with Gene Runner Software (Hasting Software, Inc., Hasting, NY) from RNA sequences from GenBank (Table 1). All primer sets had a calculated annealing temperature of $60^{\circ} \mathrm{C}$. Quantitative RT-PCR was performed in duplicate in a $25 \mu \mathrm{l}$ reaction volume consisting of $2 \mathrm{X}$ SYBR Green PCR Master Mix (Applied Biosystems), $900 \mathrm{nM}$ of each primer and 2-3 $\mu$ of cDNA. Amplification conditions were $2 \mathrm{~min}$ at $50^{\circ} \mathrm{C}, 10 \mathrm{~min}$ at $95^{\circ} \mathrm{C}$ and 40 cycles of denaturation for $15 \mathrm{~s}$ and annealing/extension at $60^{\circ} \mathrm{C}$ for $10 \mathrm{~min}$. Data from real-time assays were calculated using the v1.7 Sequence Detection Software from PE Biosystems (Foster City, CA). Relative expression of VEGF, TNF alpha and IL10 mRNA was calculated using the comparative Ct method as previously described. All values were normalized to the beta actin genes and reported as fold change over background levels detected in RA.

\section{Biochemical analysis of rheumatoid markers}

Determination of serum rheumatoid factor (RF):

- Serum rheumatoid factor (RhF) was detected by ELISA kit and supplied by QUANTA Lite

\begin{tabular}{|c|l|c|}
\hline & Primer sequence & $\begin{array}{c}\text { Annealing } \\
\text { temperature }\end{array}$ \\
\hline $\begin{array}{c}\text { MMP- } \\
3\end{array}$ & $\begin{array}{l}\text { Forwardprimer:5TCTTCAAGGACCTACCTCAGGC-3 } \\
\text { Reverseprimer:5GCTAAGGCAAAGCTGCTAGGTC-3 }\end{array}$ & $60^{\circ} \mathrm{C}$ \\
\hline IL-10 & $\begin{array}{l}\text { Forwardprimer:5 -AGTTGGACAACAAACCCTGC -3 } \\
\text { Reverseprimer:5- AAGCCCAAAGTCCATCAGTG -3 }\end{array}$ & $56^{\circ} \mathrm{C}$ \\
\hline COMP & $\begin{array}{l}\text { Forwardprimer:5 - ATGGGAGCAAGTCAGTGGAC -3 } \\
\text { Reverseprimer:5- TTGAGGTAGCTGCACTGTGG -3 }\end{array}$ & $65^{\circ} \mathrm{C}$ \\
\hline TN-actin alpha & $\begin{array}{l}\text { Forward primer : } \\
\text { 5'-GGCAGGTCTACTTTGGAGTCATTGC-3'- } \\
\text { Reverse primer: } \\
\text { 5'-ACATTCGGGGATCCAGTGAGCTCCG-3' }\end{array}$ & $\begin{array}{l}\text { 5- ACTGCCGCATCCTCTTCCTC - 3 } \\
\text { Reverse primer: } \\
\text { 5- ACTCCTGCTTGCTGATCCACAT -3 }\end{array}$ \\
\hline
\end{tabular}

Table 1: Sequence of the primers used for real-time PCR. 
Citation: El-denshary ESM, Rashed LA, Elhussiny M (2012) Immunosuppressive Effects of Mesenchymal Stem Cells versus Corticosteroid in Experimental Model of Arthritis. Clin Exp Pharmacol S5:003. doi:10.4172/2161-1459.S5-003

Page 3 of 10

- Blood ESR: was supplied by Diamond diagnostics.

- Serum (ANA): was detected by ELISA kit and supplied by QUANTA Lite

- Serum ( $\mathrm{IgG}$ ): was detected by ELISA kit and supplied by QUANTA Lite

- Serum (CRP): was detected by ELISA kit and supplied by DRG

\section{Biochemical analysis of oxidative stress biomarkers}

Measurement of serum MDA: To measure the MDA activity, R1 $100 \mathrm{ml}$ of serum MDA $1 \mathrm{~mL}$ PBS, pH 7.0 was collected in dry centrifuge tubes by means of small short-neck funnels. The tubes were placed in an inclined position for 5 minutes, allowed to coagulate, and then placed in an incubator at $37^{\circ} \mathrm{C}$ for 10 minutes. Centrifugation at 1000 $\mathrm{xg}$ for 20 minutes was performed and the clear sera were separated and kept in the refrigerator till use. The absorbance was measured and the sera were calculated by using standard curve.

Measurement of serum LDH: To measure the LDH activity, R1 $100 \mathrm{ml}$ of serum LDH $1 \mathrm{~mL}$ PBS, pH 7.0 was collected in dry centrifuge tubes by means of small short-neck funnels. The tubes were placed in an inclined position for 5 minutes, allowed to coagulate, and then placed in an incubator at $37^{\circ} \mathrm{C}$ for 10 minutes. Centrifugation at 1000 $\mathrm{xg}$ for 20 minutes was performed and the clear sera were separated and kept in the refrigerator till use. The absorbance was measured and the sera was calculated by using standard curve

Measurement of tissue MPO: MPO concentration was measured from knee joint homogenate in phosphate buffer $\mathrm{pH} 8.0$ and then 5\% TCA was added, to precipitate knee joint protein. After centrifugation, dithiobisnitrobenzoate (DTNB) solution was added to the supernatants of knee joint homogenate, and incubated for 1 hour. The absorbance was measured. Concentration of MPO in knee joint tissue was calculated using the standard curve R2. The knee joint protein concentration was calculated by using standard curve of bovine serum albumin (BSA) solution.

Measurement of tissue GSH: GSH concentration was measured from knee joint homogenate in phosphate buffer $\mathrm{pH} 8.0$ and then 5\% TCA was added, to precipitate liver protein. After centrifugation, Dithiobisnitrobenzoate (DTNB) solution was added to the supernatants of knee joint homogenate, and incubated for 1 hour. The absorbance was measured. Concentration of GSH in knee joint tissue was calculated using the standard curve R2. The knee joint protein concentration was calculated by using standard curve of Bovine Serum Albumin (BSA) solution.

Measurement of tissue catalase: Catalase (CAT) activity in knee joint homogenate was detected using ammonium molybdate method by measuring the intensity of a yellow complex formed by molybdate and $\mathrm{H}_{2} \mathrm{O}_{2}$ at $405 \mathrm{~nm}$, after ammonium molybdate was added to terminate the $\mathrm{H}_{2} \mathrm{O}_{2}$ degradation reaction catalyzed by CAT. An enzyme activity unit was defined as the degradation of $1 \mathrm{mmol} \mathrm{H}_{2} \mathrm{O}_{2}$ per second per $\mathrm{mg}$ tissue protein and the enzyme activity was expressed as $\mathrm{U} / \mathrm{mg}$ protein (R4).

\section{Analysis of knee joint histopathology}

The obtained tissue sections were collected on glass slides, deparaffinized, stained by Hematoxylin and eosin and examination was done through the light electric microscope.

\section{Statistical analysis}

Data were expressed as mean \pm SE. Significant differences were determined by using ANOVA and post-hoc tests (LSD) for multiple comparisons using SPSS 9.0 computer Software. Results were considered significant at $\mathrm{p}<0.05$.

\section{Results}

\section{MSCs culture, identification and homing}

Isolated and cultured undifferentiated MSCs reached 70$80 \%$ confluence at 14 days. In vitro osteogenic and chondrogenic differentiation of MSCs were confirmed by morphological changes and special stains (Figures 1A, 1B, 2A and 2B) in addition MSCs were identified by surface marker CD29 and CD105 by flow cytometry (Figures 3A and 3B). MSCs labeled with PKH26 fluorescent dye was detected in the joint knee tissues confirming that these cells homed into the joint knee tissue (Figure 4).

\section{MSCs and betamethasone improve clinical paw edema}

The results of the present study show a significant decrease in the clinical paw edema of betamethasone model and complete improvement in MSC compared to the CIA group $((\mathrm{P}<0.05)$ (Tables 2 and 3 ).

\section{$\mathrm{X}$-Ray filming results in MSCs and betamethasone models of arthritis}

Joints of all animals in group-I-II and group-III in betamethasone model were radiologically normal (grade 0 ). Whereas those of groupIV showed relative narrowing of joint spaces, mild focal subchondral sclerosis of proximal tibial end, mild erosion of the lateral tibial condyle (grade 2). While those of figure 5 showed relative narrowing of joint spaces, no fracture lines seen, no osteolytic or sclerotic bony lesions or bone deformity, no evidence of soft tissue masses and no loose bodies seen (grade 1). But in MSC model joints of all animals in group-I and II were radiologically normal (grade 0 ). Whereas those of group-III showed narrowing of joint space with destruction of joint surfaces
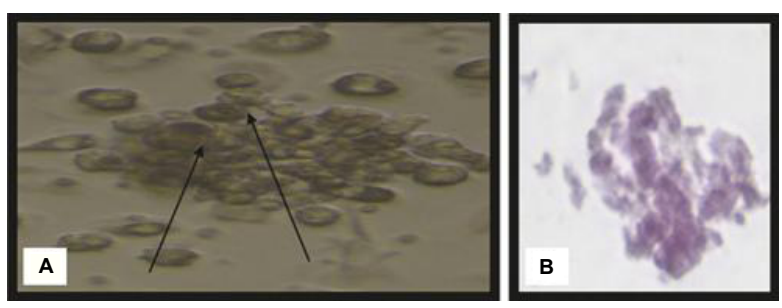

Figure 1: Morphological and histological staining of differentiated BM-MSCs into osteoblasts. (A) $(\times 20)$ Arrows for differentiated MSCs osteoblasts after addition of growth factors. (B) $(\times 200)$ Differentiated MSCs into osteoblasts stained with Alizarin red stain.

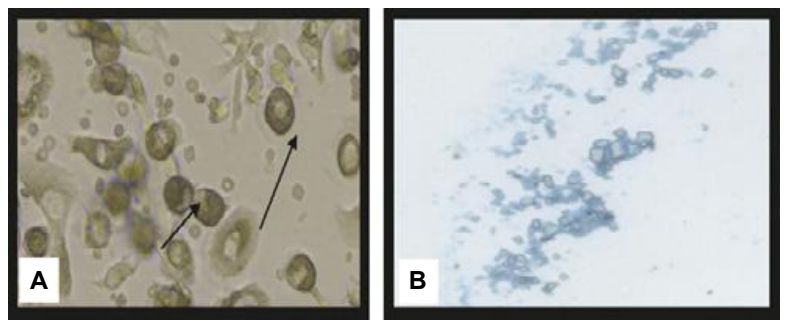

Figure 2: Morphological and histological staining of differentiated BM-MSCs into chondrocytes. $(A)(\times 20)$ Arrows for differentiated MSCs chondrocytes after addition of growth factors. (B) $(\times 200)$ Differentiated MSCs into chondrocytes stained with Alcian blue stain. 
Citation: El-denshary ESM, Rashed LA, Elhussiny M (2012) Immunosuppressive Effects of Mesenchymal Stem Cells versus Corticosteroid in Experimental Model of Arthritis. Clin Exp Pharmacol S5:003. doi:10.4172/2161-1459.S5-003

Page 4 of 10
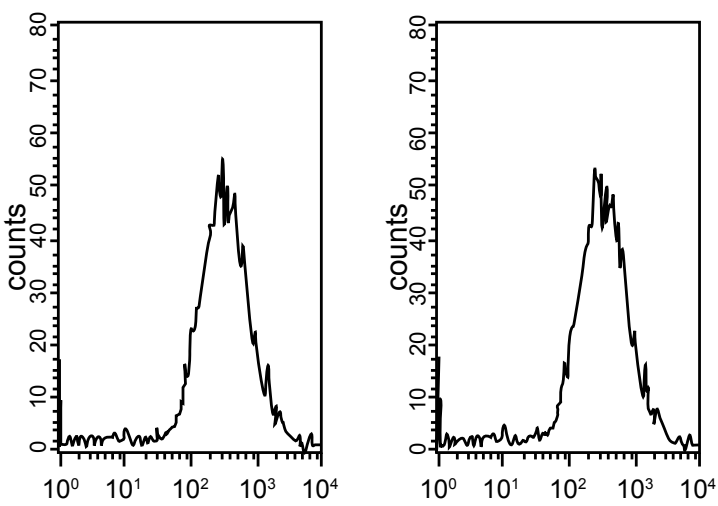

Figure 3: Flow cytometric characterization analyses of bone marrow-derived MSCs. Cells were uniformly positive for CD105 (A), and positive for CD29 (B).

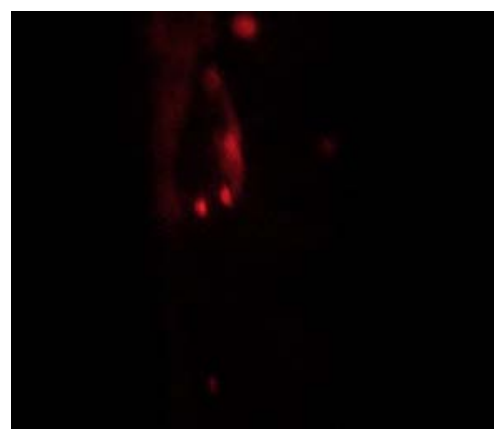

Figure 4: Detection of MSCs labeled with PKH26 fluorescent dye in joint knee tissue. MSCs labeled with the PKH26 showed strong red autofluorescence after transplantation into mice, confirming that these cells were seeded into the joint knee tissue.

(70\%) associated with bony sclerosis, osteophytic lippings, bowing deformity of both tibial bones with ostepenic texture and notable swelling of surrounding soft tissue (grade 4), and those of group-IV showed normal osseous architecture of scanned bones, no fracture lines seen intact joint space, no osteolytic or sclerotic bony lesions or bone deformity, no evidence of soft tissue masses and no loose bodies seen (grade 0 ).

Radiological scoring of all animals was summarized in figures $5 \mathrm{~A}$ and $5 \mathrm{~B}$.

\section{Biochemical assessment of rheumatoid markers after MSCs and betamethasone treatment in CIA models}

The results of the present study show a significant decrease in RhF, ESR, ANA, CRP and IgG of betamethasone model and complete improvement in MSC compared to the CIA group $((\mathrm{P}<0.05)$ (Table 4)).

Biochemical assessment of oxidative stress biomarkers after MSCs and betamethasone treatment in CIA models

The results of the present study show a significant decrease in $\mathrm{LDH}$, MDA and MPO enzymes and a significant increase in GSH, CAT enzymes of betamethasone model and complete improvement in MSC compared to the CIA group $((\mathrm{P}<0.05)$ (Table 5$))$.

\section{Gene expression of MMP-3, COMP, IL-10, TNF- $\alpha$ genes}

Concerning gene expression, there was significant decrease in the
MMP-3, COMP and TNF- $\alpha$ genes and a significant increase in IL-10 gene of MSC compared to the CIA group $((\mathrm{P}<0.05)$ (Figure 6)).

\section{Histopathological examination of knee joint in different groups}

Histopathological examination of knee joint of the mice received phosphate buffer saline, acetic acid and betamethasone in betamethasone model, showed normal structure of bone and normal synovial membrane (score 0). While in CIA showed moderate erosion of articular cartilage, moderate destruction of bone, edema, moderate synovial proliferation and inflammatory cell infiltrate, and a massive influx of inflammatory cells into the subsynovial connective tissue (score 2). In addition CIA treated with betamethasone showed nearly normal structure of bone, no erosion of articular cartilage, no inflammatory cell infiltrate, no edema and normal synovial membrane (score 1). Furthermore in MSC model, the knee joints sections of the mice received saline and acetic acid showed normal structure of bone, normal articular cartilage and normal synovial membrane (score 0 ). While in CIA showed severe erosion of articular cartilage, severe destruction of bone, edema, exudates, marked proliferation of synovial membrane, thickening of synovial membrane and a massive influx of inflammatory cells into the subsynovial connective tissue (score 4). Also in CIA treated with MSC showed normal articular cartilage, normal synovial membrane, no inflammatory cell infiltrate, no edema, no exudates and no proliferation of synovial membrane (score 0 ) (Figures 7A and 7B).

\section{Visual histological assessment of arthritis}

All mice were examined two to three times per week for the initial visual appearance of arthritis after CII injection. Arthritis of each paw was graded using the following scoring system: I, 0 , normal; II, apparent swelling and redness limited to individual digits; III, swelling in more than one joint; IV, severe redness and swelling of the entire paw including digits; and $\mathrm{V}$, maximally inflamed paw with involvement of multiple joints (Figure 8).

\section{Discussion}

Bone marrow-derived stem cells contribute to cell turnover and repair in various tissue types, including the knee joint $[15,16]$. MSCs are commonly defined as bone marrow-derived fibroblastlike cells, which despite the lack of specific surface markers can be selected by their adherence characteristics in vitro and which have the ability to differentiate along the three principal mesenchymal lineages: osteoblastic, adipocytic and chondrocytic $[17,18]$. The studies demonstrated that MSC are non-immunogenic and display immunosuppressive properties, with the ability to inhibit maturation of dendritic cells and to suppress the fraction of memory T cells, B cells and NK cells, Also its transdifferentiation and antiapoptotic ability. These properties of MSC render these cells especially attractive for therapeutic application in several inflammatory and neurodegenerative disease, as well as in regenerative medicine [19]. In the present study, bone marrow derived mesenchymal stem cells were isolated from male mice, grown and characterized by their adhesiveness and fusiform shape and by detection of CD 29, one of surface marker of mice mesenchymal stem cells and were used to detect their possible antiinflammatory and transdifferentiation role in amelioration of arthritis compared to betamethasone in experimental model of arthritis and we tested whether MSC and betamethasone could improve arthritis. Zhou et al. [19] reported that human MSC could significantly inhibit the autoimmune progression in mice. In this study, we further 
Citation: El-denshary ESM, Rashed LA, Elhussiny M (2012) Immunosuppressive Effects of Mesenchymal Stem Cells versus Corticosteroid in Experimental Model of Arthritis. Clin Exp Pharmacol S5:003. doi:10.4172/2161-1459.S5-003

Page 5 of 10

\begin{tabular}{|c|c|c|c|c|c|c|c|c|}
\hline \multirow{2}{*}{$\begin{array}{l}\text { Days } \\
\text { Groups }\end{array}$} & \multicolumn{5}{|c|}{ Scores $(\mathrm{mm})$} \\
\cline { 2 - 7 } & 0 & 3 & 7 & 11 & 15 & 21 \\
\hline Phosphate buffer saline & $0 \pm 0$ & $0 \pm 0$ & $0 \pm 0$ & $0 \pm 0$ & $0 \pm 0$ & $0 \pm 0$ \\
\hline Acetic acid & $0 \pm 0$ & $0 \pm 0$ & $0 \pm 0$ & $0 \pm 0$ & $0 \pm 0$ & $0 \pm 0 \pm 0$ \\
\hline Betamethosone & $0 \pm 0$ & $0 \pm 0$ & $0 \pm 0$ & $0 \pm 0$ & $0 \pm 0$ & $0 \pm 0$ \\
\hline CIA & $0 \pm 0$ & $0.009 \pm 0.0002$ & $0.015 \pm 0.0006$ & $0.018 \pm 0.0006$ & $0.035 \pm 0.0015$ & $0.038 \pm 0.0014$ & $0.04 \pm 0.0015$ & $0.04 \pm 0.0014$ \\
\hline CIA + Betamethosone & $0 \pm 0$ & $0.008 \pm 0.0002$ & $0.016 \pm 0.0006$ & $0.018 \pm 0.0006$ & $0.015 \pm 0.0006^{*}$ & $0.013 \pm 0.0005^{*}$ & $0.009 \pm 0.0003^{*}$ & $0.004 \pm 0.0001^{*}$ \\
\hline
\end{tabular}

"Significant difference between CIA treated group and CIA + Betamethosonegroup using t-student test at $\mathrm{P}<0.001$

Table 2: Effects of betamethasone on paw edema scoring in CIA mice.

\begin{tabular}{|c|c|c|c|c|c|c|c|c|c|c|c|c|c|}
\hline \multirow{2}{*}{$\begin{array}{l}\text { Days } \\
\text { Groups }\end{array}$} & \multicolumn{13}{|c|}{ Scores (mm) } \\
\hline & 0 & 3 & 7 & 11 & 15 & 18 & 21 & 25 & 28 & 31 & 34 & 38 & 42 \\
\hline Saline & $0 \pm 0$ & $0 \pm 0$ & $0 \pm 0$ & $0 \pm 0$ & $0 \pm 0$ & $0 \pm 0$ & $0 \pm 0$ & $0 \pm 0$ & $0 \pm 0$ & $0 \pm 0$ & $0 \pm 0$ & $0 \pm 0$ & $0 \pm 0$ \\
\hline Acetic acid & $0 \pm 0$ & $0 \pm 0$ & $0 \pm 0$ & $0 \pm 0$ & $0 \pm 0$ & $0 \pm 0$ & $0 \pm 0$ & $0 \pm 0$ & $0 \pm 0$ & $0 \pm 0$ & $0 \pm 0$ & $0 \pm 0$ & $0 \pm 0$ \\
\hline $\mathrm{ClA}$ & $0 \pm 0$ & $0.009 \pm 0.0002$ & $\begin{array}{c}0.015 \\
\pm 0.0006\end{array}$ & $\begin{array}{c}0.019 \\
\pm 0.0006\end{array}$ & $\begin{array}{c}0.035 \\
\pm 0.0013\end{array}$ & $\begin{array}{c}0.038 \\
\pm 0.0014\end{array}$ & $\begin{array}{l}\quad 0.04 \\
\pm 0.0015\end{array}$ & $\begin{array}{l}0.04 \pm \\
0.0014\end{array}$ & $\begin{array}{l}0.04 \pm \\
0.0014\end{array}$ & 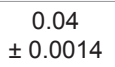 & $\begin{array}{c}0.042 \\
\pm 0.0015\end{array}$ & $\begin{array}{c}0.041 \\
\pm 0.0015\end{array}$ & $\begin{array}{c}0.041 \\
\pm 0.0015\end{array}$ \\
\hline $\mathrm{ClA}+\mathrm{MSC}$ & $0 \pm 0$ & $\begin{array}{c}0.008 \\
\pm 0.0002\end{array}$ & $\begin{array}{c}0.016 \\
\pm 0.0006\end{array}$ & $\begin{aligned} & 0.02 \\
\pm & 0.0007\end{aligned}$ & $\begin{array}{c}0.035 \\
\pm 0.0015\end{array}$ & 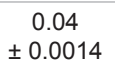 & $\begin{array}{ll} & 0.04 \\
\pm & 0.0015\end{array}$ & $\begin{array}{c}0.038 \\
\pm 0.0014\end{array}$ & $\begin{array}{l}0.03^{*} \\
\pm 0.0011\end{array}$ & $\begin{array}{c}0.021^{*} \pm \\
0.0008\end{array}$ & $\begin{array}{c}0.017^{\star} \\
\pm 0.0006\end{array}$ & $\begin{array}{c}0.011^{*} \\
\pm 0.0004\end{array}$ & $\begin{array}{c}0.003^{*} \\
\pm 0.0001\end{array}$ \\
\hline
\end{tabular}

"Significant difference between CIA treated group and CIA + MSC treated group using t-student test at $\mathrm{P}<0.001$

Table 3: Effects of MSC on paw edema scoring in CIA mice.

PBS
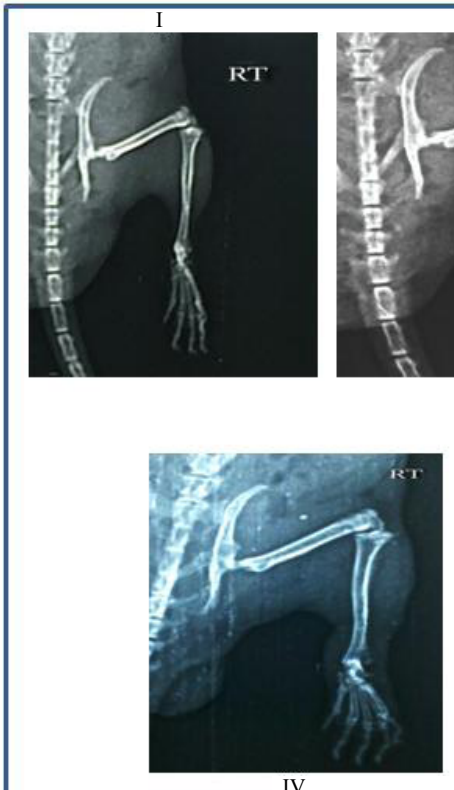

CIA
Acetic acid
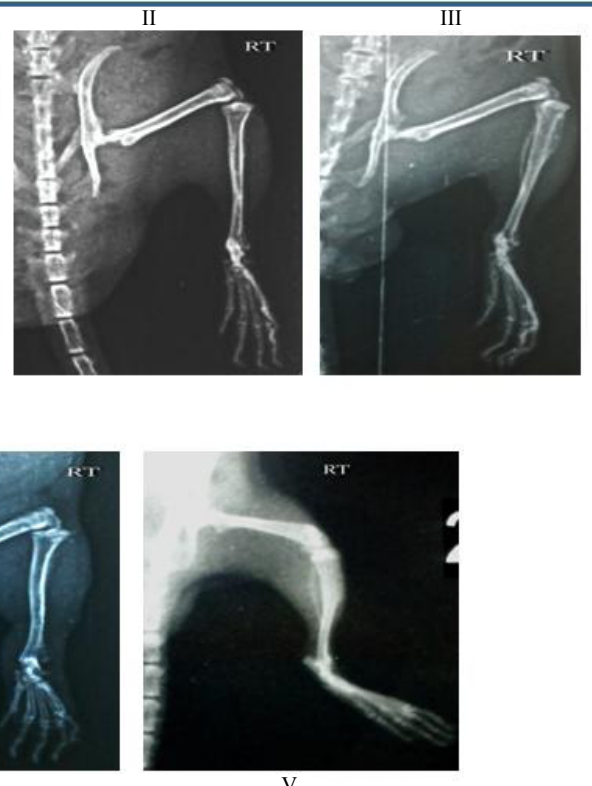

CIA + Betamethasone

Figure 5a: X-Ray filming in betamethasone model of arthritis: normal control, grade 0 (I, II, III) IA, showed relative narrowing of joint spaces and mild erosion of the lateral tibial condyle, grade 2 (IV). CIA+betamethasone, showed relative narrowing of joint spaces, no osteolytic or sclerotic bony lesions and no loose bodies seen, grade 1. (V).

expanded the possible clinical utility of MSCs to the treatment of RA. Specifically, we found that injection of MSCs into CIA mice led to a significant reduction in arthritic severity. The paw swelling completely disappeared after MSC administration in CIA/MSC mice. RA is a T cell-mediated autoimmune disease. Both antigen-activated CD4 T helper 1 (Th1) and CD8 T cells are reported to be involved in RA pathogenesis $[20,21]$. When triggered by antigenic peptides such as CII, a major component of hyaline cartilage acting as an autoantigen in RA [22,23], T cells stimulate monocytes, macrophages, and synovial fibroblasts to secrete proinflammatory cytokines such as TNF- $\alpha$ [24]. Here we show that MSC injection to CIA mice results in a rapid reversal of tissue inflammation. We further show that such a drastic effect is accompanied by a diminished tissue level of TNF- $\alpha$ and elevated production of anti-inflammatory cytokine IL-10 in CIA/MSC mice. These results are consistent with previous findings by others $[25,26]$ showing the immunosuppressive effect of MSCs, and our data revealed that MSCs can be a potent candidate therapeutic treatment for RA. Studies by have clearly shown that regulation of cytokine levels 
Citation: El-denshary ESM, Rashed LA, Elhussiny M (2012) Immunosuppressive Effects of Mesenchymal Stem Cells versus Corticosteroid in Experimental Model of Arthritis. Clin Exp Pharmacol S5:003. doi:10.4172/2161-1459.S5-003

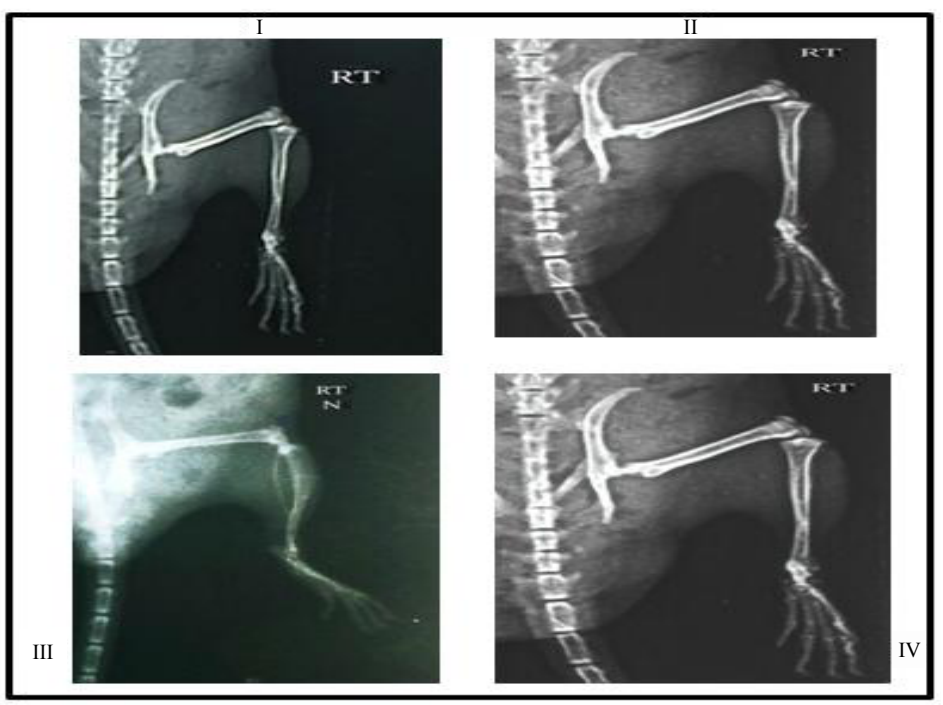

CIA

CIA + MSC

Figure 5b: X-Ray filming results in MSCs model of arthritis: normal control, grade 0 (I,II)

$\mathrm{CIA}$,showed narrowing of joint space with destruction of joint surfaces $(70 \%)$ associated with bony sclerosis, and notable swelling of surrounding soft tissue, grade 4 (III).

CIA + MSC, showed normal osseous architexure of scanned bones, no osteolytic or sclerotic bony lesions and no loose bodies seen, grade 0 (IV).

\begin{tabular}{|c|c|c|c|c|c|}
\hline \multirow{2}{*}{ Groups } & \multicolumn{5}{|c|}{ Mean \pm SE } \\
\hline & $\lg G(\mathrm{mg} / \mathrm{dl})$ & Rh factor (IU/ml) & $\mathrm{ESR}(\mathrm{ml} / \mathrm{h})$ & ANA (U/I) & CRP (mg/l) \\
\hline Phosphate buffer & $800.4 \pm 7.3$ & $10.50 \pm 1.57$ & $6.84 \pm 0.04$ & $0.002 \pm 0.0002$ & $1.42 \pm 0.03$ \\
\hline Acetic acid & $819.7 \pm 8.5$ & $11.21 \pm 0.29$ & $6.98 \pm 0.20$ & $0.001 \pm 0.0001$ & $1.62 \pm 0.04$ \\
\hline Betamethosone & $805.1 \pm 15.2$ & $11.18 \pm 0.50$ & $6.92 \pm 0.27$ & $0.001 \pm 0.0001$ & $1.56 \pm 0.05$ \\
\hline $\mathrm{CIA}$ & $1750.3 \pm 46.8^{*}$ & $37.60 \pm 0.77^{*}$ & $34.28 \pm 1.50^{*}$ & $1.558 \pm 0.0738^{*}$ & $8.09 \pm 0.16^{*}$ \\
\hline $\mathrm{CIA}+$ Betamethosone & $890.8 \pm 38.9 \$$ & $16.90 \pm 0.31 * \$$ & $10.70 \pm 0.20 \$$ & $0.016 \pm 0.0003 \$$ & $3.18 \pm 0.06^{*} \$$ \\
\hline Saline & $812.40 \pm 5.68$ & $10.81 \pm 1.76$ & $7.03 \pm 0.13$ & $0.002 \pm 0.0002$ & $1.45 \pm 0.03$ \\
\hline Acetic acid & $806.39 \pm 10.64$ & $11.30 \pm 0.29$ & $7.01 \pm 0.20$ & $0.001 \pm 0.0001$ & $1.65 \pm 0.04$ \\
\hline CIA & $1952.10 \pm 45.65^{*}$ & $44.95 \pm 0.92^{*}$ & $43.12 \pm 0.80^{*}$ & $1.610 \pm 0.0328^{*}$ & $9.18 \pm 0.30^{*}$ \\
\hline $\mathrm{CIA}+\mathrm{MSC}$ & $819.83 \pm 29.65 \$$ & $12.43 \pm 0.78 \$$ & $6.83 \pm 0.09 \$$ & $0.003 \pm 0.0004 \$$ & $1.68 \pm 0.05 \$$ \\
\hline
\end{tabular}

*Significantly different from the respective acetic acid treated group value at $\mathrm{P}<0.05$

$\$$ Significantly different from the respective CIA treated group value at $P<0.0$

Table 4: Effect of betamethasone and MSCs treatments on rheumatoid markers in the studied groups.

\begin{tabular}{|c|c|c|c|c|c|}
\hline \multirow{2}{*}{ Groups } & \multicolumn{5}{|c|}{ Mean \pm SE } \\
\hline & $\mathrm{LDH}(\mathrm{u} / \mathrm{l})$ & MDA nmol/l)) & CAT (u/g) & GSH $(u / g)$ & MPO (u/g) \\
\hline Phosphate buffer saline & $370.8 \pm 5.0$ & $9.65 \pm 0.17$ & $25.42 \pm 1.05$ & $7.15 \pm 0.11$ & $1.48 \pm 0.04$ \\
\hline Acetic acid & $377.5 \pm 8.8$ & $9.74 \pm 0.25$ & $25.82 \pm 0.85$ & $6.98 \pm 0.25$ & $1.56 \pm 0.04$ \\
\hline Betamethosone & $374.3 \pm 8.4$ & $9.32 \pm 0.27$ & $25.54 \pm 0.77$ & $6.98 \pm 0.33$ & $1.45 \pm 0.11$ \\
\hline $\mathrm{CIA}$ & $675.7 \pm 12.6^{*}$ & $20.84 \pm 0.43^{*}$ & $8.34 \pm 0.32^{*}$ & $2.95 \pm 0.29^{*}$ & $3.95 \pm 0.17^{*}$ \\
\hline $\mathrm{ClA}+$ & $406.0 \pm 7.6 * \$$ & $13.10 \pm 0.24 \$$ & $21.06 \pm 0.39 * \$$ & $4.83 \pm 0.09^{*} \$$ & $2.10 \pm 0.04^{*} \$$ \\
\hline Saline & $372.40 \pm 4.66$ & $9.61 \pm 0.15$ & $25.04 \pm 0.81$ & $7.23 \pm 0.23$ & $1.49 \pm 0.02$ \\
\hline Acetic acid & $373.89 \pm 9.13$ & $9.78 \pm 0.25$ & $25.97 \pm 0.81$ & $7.01 \pm 0.52$ & $1.58 \pm 0.04$ \\
\hline $\mathrm{CIA}$ & $706.21 \pm 17.80$ * & $29.04 \pm 0.59^{*}$ & $8.33 \pm 0.53^{*}$ & $2.95 \pm 0.29^{*}$ & $4.15 \pm 0.18^{*}$ \\
\hline $\mathrm{ClA}+\mathrm{MSC}$ & $384.14 \pm 15.99 \$$ & $12.23 \pm 0.25 \$$ & $23.11 \pm 0.40 \$$ & $7.10 \pm 0.78 \$$ & $1.93 \pm 0.08 \$$ \\
\hline
\end{tabular}

*Significantly different from the respective acetic acid treated group value at $\mathrm{P}<0.05$

$\$$ Significantly different from the respective CIA treated group value at $\mathrm{P}<0.05$

Table 5: Effect of betamethasone and MSCs treatments on oxidative stress biomarkers in the studied groups.

in patients with RA may be a novel approach to the treatment of these diseases. In particular, those investigators described the successful treatment of refractory RA by intravenous (IV) infusion of antibodies to TNF- $\alpha$, suggesting a key role for this cytokine in the pathogenesis of chronic arthritis. Also in this study we found that MSC which is superior to betamethasone treatment improved arthritis in ESR, RhF 
Citation: El-denshary ESM, Rashed LA, Elhussiny M (2012) Immunosuppressive Effects of Mesenchymal Stem Cells versus Corticosteroid in Experimental Model of Arthritis. Clin Exp Pharmacol S5:003. doi:10.4172/2161-1459.S5-003

Page 7 of 10

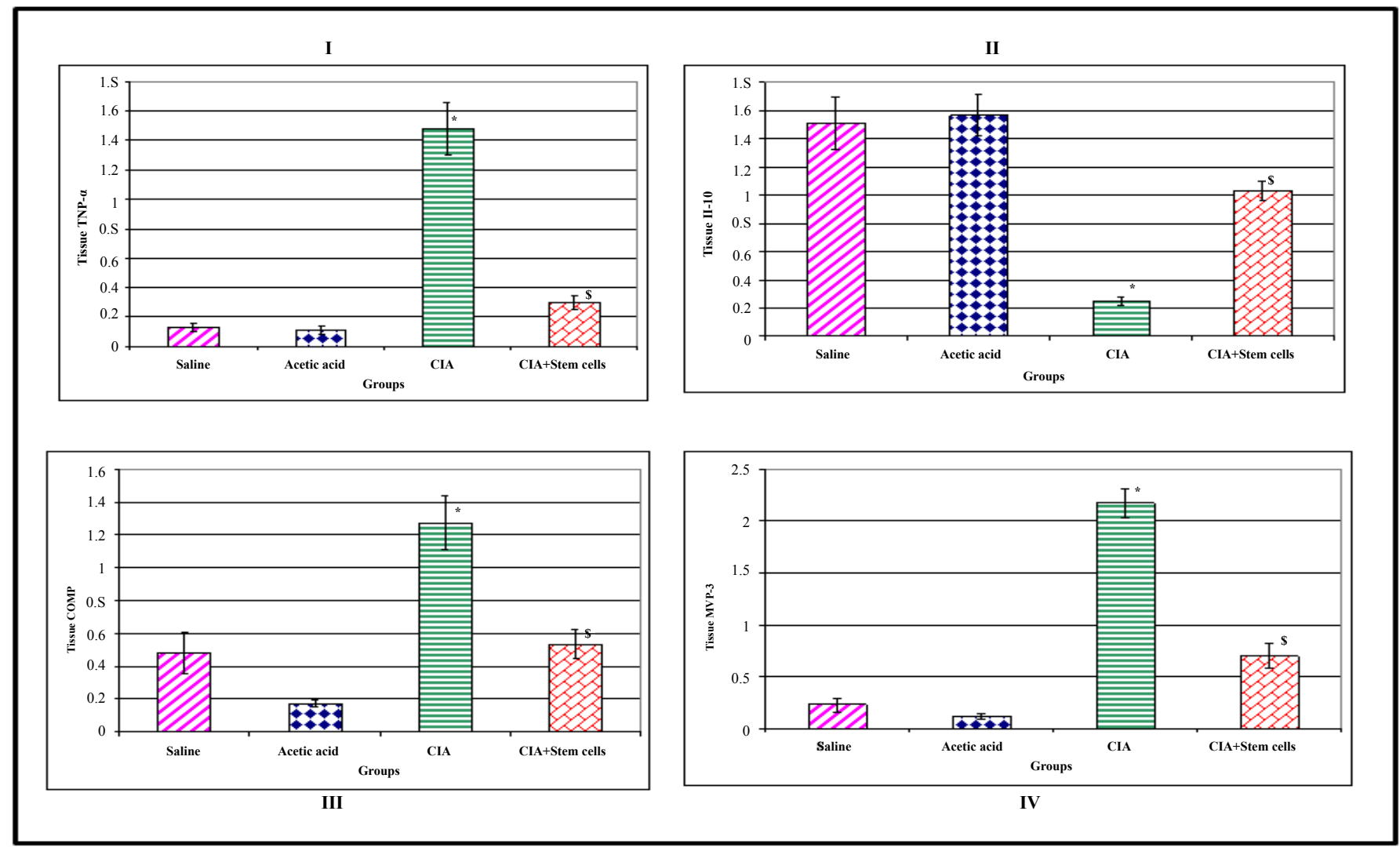

*Significantly different from the respective acetic acid treated group value at $P<0.05$ $\$$ Significantly different from the respective CIA treated group value at $\mathrm{P}<0.05$

Figure 6: Effect of MSCs treatment on TNF-a (I), IL-10 (II), COMP (III) and MMP3 (IV) gene expressions in the studied groups.

and CRP. These results are consistent with previous findings by others Li et al. [27] who stated that patients with blood rheumatoid arthritis factor (BRAF)-specific antibodies had significantly higher ESRs than patients without these antibodies ( $\mathrm{p}=0.040$ for anti-BRAF and $\mathrm{p}=0.030$ ). Patients with prolonged disease had a significantly higher prevalence of anti-BRAF (18/62 patients) than patients with recent-onset disease $(2 / 35$ patients) $(\mathrm{p}=0.006)$. A weak but significant correlation was found between anti-RhF antibodies and ESRs in both acute and chronic RA patients $(r=0.319, p=0.004)$. Silva et al. [28] stated that the significant correlation between ESR and CRP, and their non-specificity for RA, indicated that it will not be necessary to perform both evaluations. CRP yielded a better activity score more often than ESR, but with $84.7 \%$ of concordance in the disease activity status, indicating that both measures are useful for assessing disease activity in RA. Furthermore the correlation between Disease Activity Scores (DAS) and Clinical Disease Activity Index (CDAI), and also between Simplified Disease Activity Index (SDAI)-CDAI may enable physicians to easily assess the disease activity without ESR or CRP values. Level of the lipid peroxidation is significantly higher in the patients with RA than in the control group and it is in agreement with most studies Sarban et al. [29]. On the basis of the obtained results and the literature data, it can be concluded that in RA, red blood cells are more susceptible to the influence of free radicals Staroń et al. [30].

Sarban et al. [29] observed inhibition of CAT and GSH activities. His results confirm increase in oxidative stress in RA patients, while, Staron et al. [30] stated that there is no significant difference between
CAT and GSH activities as regarding RA. In Sarban et al. [29] study, the concentration of the GSH is about $20 \%$ lower in RA patients than in healthy subjects. The present study had been supported by the study of Torsteinsdóttir et al. [31] which found that elevated serum levels of lysozyme together with elevated serum levels of MPO were observed in patients with RA compared with controls. Their study based on the results of previous investigations indicating that lysozyme in serum predominantly originates from monocytes/macrophages and to a lesser degree from neutrophils, that MPO originates from monocytes and neutrophils Resnitzky et al. [32].

Lysozyme is produced continuously by monocytes and macrophages, although macrophages have a higher basal production of lysozyme. Tumor necrosis factor- $\alpha$ (TNF- $\alpha$ ) stimulates lysozyme production by monocytes and macrophages and the release of lysozyme and MPO by neutrophils. Furthermore, elevated levels of TNF- $\alpha$ in serum have been measured in RA. The increased secretion of lysozyme into the peripheral blood could thus be mediated by TNF- $\alpha$ Torsteinsdóttir et al. [31].

COMP is an extracellular glycoprotein and is a member of the thrombospondin family of calcium-binding proteins. COMP is associated with cartilage breakdown and has been studied as a potential diagnostic and prognostic indicator as well as a marker of disease severity or the efficacy of treatment Tseng et al. [33].

It has been reported that COMP concentrations in Synovial Fluid (SF) are 10 times higher than in serum and that higher COMP 
Citation: El-denshary ESM, Rashed LA, Elhussiny M (2012) Immunosuppressive Effects of Mesenchymal Stem Cells versus Corticosteroid in Experimental Model of Arthritis. Clin Exp Pharmacol S5:003. doi:10.4172/2161-1459.S5-003

Page 8 of 10

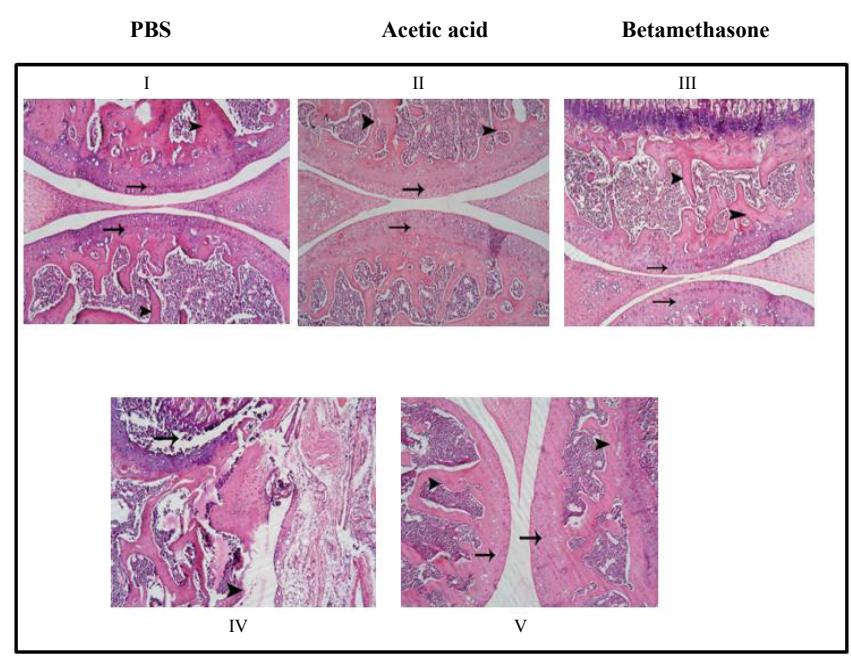

Figure 7a: Histopathological examination of Knee joint in different groups. normal control, showed normal structure of bone, score 0 (I, II, III). $\mathrm{CIA}$, showed moderate erosion of articular cartilage, edema, and a massive influx of inflammatory cells into the subsynovial connective tissue, score 2. (IV).

$\mathrm{CIA}+$ betamethasone, showed no erosion of articular cartilage, no edema and normal synovial membrane, score 1. (V).

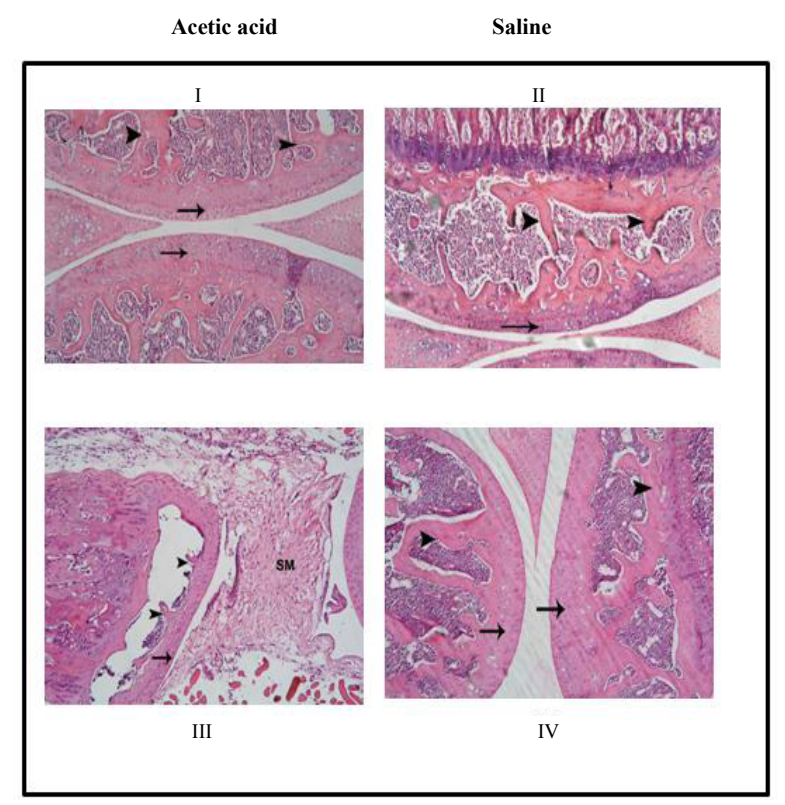

Figure 7b: Histopathological examination of Knee joint in different groups. normal control,showed normal structure of bone, score 0 . (I, II)

$\mathrm{CIA}$, showed severe erosion of articular cartilage, severe destruction of bone, edema, exudates, and a massive influx of inflammatory cells into the subsynovial connective tissue, score 4.(III): CIA+MSC, showed normal articular cartilage, no edema, no exudates and no proliferation of synovial membrane, score 0. (IV).

concentrations have been observed in patients with higher radiographic Kellgren-Lawrence grades. However, despite these expectations, Kokebie et al. [34] were not able to identify an association of COMP concentrations with the type of disease or its severity, perhaps because of the limitations of their study. In this study, antirheumatic activities of betamethazone and MSC were documented. Although betamethasone exhibited moderate antirheumatic activities, it suppressed paw swelling, decreased bone erosion in mice and slightly reduced the RAinduced bone resorption in rats.

Contrary to these results Higaki et al. [35] stated that intravenous administration to arthritic rats and mice showed that the PLGA-betamethasone system was more effective at reducing the inflammatory response than the free glutocorticoid. Targeting ability and, consequently, efficacy of the betamethasone was further improved by modifying the PLGA nanoparticles with PEG, forming so-called "stealth nanosteroids" Ishihara et al. [36], Ghannam et al. [37] showed contrasted results reported in rheumatoid arthritis using the experimental collagen-induced arthritis model. They first showed that injection of the allogeneic C3H10T1/2 MSC line did not reverse the disease score. In the same model, however, a single injection of primary MSCs was shown to prevent the occurrence of severe arthritis, which was associated with a decrease in serum proinflammatory cytokines. They added that the use of human adipose-derived MSCs was effective in the xenogeneic collagen-induced arthritis model. The therapeutic efficacy was associated with decreased antigen-specific Th1/Th17 cell expansion, enhanced secretion of IL-10 and generation of CD4+, CD25+, Foxp3+ and TREG cells with the capacity to suppress self-reactive T-effector responses Zheng et al. [38]. Another study reported no convincing increase of TREG cells in vivo despite in vitro evidence of T-cell inhibition by MSCs Rafei et al. [39]. Recent data with primary syngeneic and allogeneic MSCs indicate that MSCs may have a dual effect: locally, reducing the clinical signs of inflammation in the joints, probably via the secretion of antiproliferative mediators; and systemically, by switching the polarization of the host response towards a Th2 immune profile Ghannam et al. [40]. The divergent mechanistic results obtained from the various studies underline the complexity of the MSC-mediated immunosuppressive process and the differences that may be attributed to the various MSC species used Ren et al. [41] and to the different techniques of MSC isolation and culture Polchert et al. [42]. In addition the fibrinogen analysis demonstrates that fibrinogen levels increase with disease activity in the early stages of disease. In the chronic phase of the corticosteroid-treated group, an increase in fibrinogen levels indicates increased inflammatory activity. However, this was not reflected in the arthritis score at this time-point. Serum levels of COMP, determined with the methods
Grade (0)
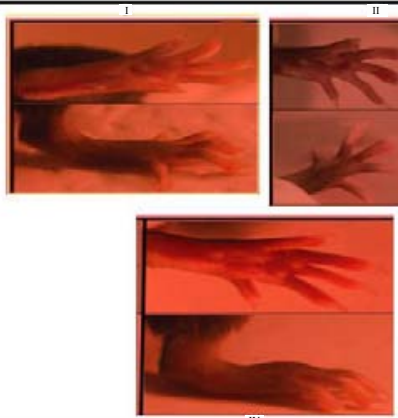

Grade (3)
Grade (1)
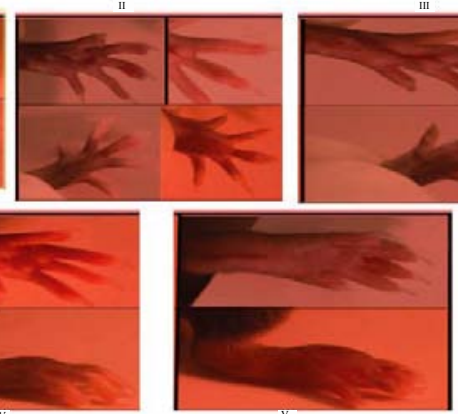

Grade (4)
Figure 8: Visual histological assessment of arthritis. I showed grade 0 , normal.

II showed grade 1, apparent swelling and redness limited to individual digits. III showed grade 2 , swelling in more than one joint.

IV showed grade 3 , severe redness and swelling of the entire paw including digits and $V$ showed grade 4, maximally inflamed paw with involvement of multiple joints. 
Citation: El-denshary ESM, Rashed LA, Elhussiny M (2012) Immunosuppressive Effects of Mesenchymal Stem Cells versus Corticosteroid in Experimental Model of Arthritis. Clin Exp Pharmacol S5:003. doi:10.4172/2161-1459.S5-003

Page 9 of 10

used in the present paper, have been shown to correlate well with ongoing cartilage destruction, both in the CIA model in mice and in other arthritis models in mice and mice [19]. We concluded from these observations that the quantification of serum COMP, in parallel with careful histological evaluation of cartilage destruction, may provide us with increased knowledge of whether corticosteroids can affect cartilage destruction, and whether serum COMP provides a useful tool for the evaluation of such a drug effect.

The development of severe arthritis in aging MMP-deficient mice is particularly noteworthy in view of the many reports in the literature of overexpression of individual MMPs in human arthritis [42,43]. This observation should be carefully considered before employing MMP inhibitors in arthritis therapy. The arthritis that develops in MMPdeficient mice bears some resemblance to both murine collageninduced arthritis and human rheumatoid arthritis; one noted element of similarity being the development of TRAP-positive osteoclastlike cells in articular and periarticular soft tissues $[44,45]$. Although other experiments have not addressed the pathogenesis of arthritis in MMP-deficient mice, they noted that interfaces between bone/cartilage and articular soft tissues are most severely affected. These are also sites where MMP is expressed at particularly high levels. In the knee for example, the insertion of the cruciate ligament where ligament, bone, and articular cartilage interface was most profoundly affected. These observations raise the question whether the arthritic changes in MMPdeficient mice develop as a result of inappropriate remodeling during growth [46]. Furthermore, the function of bone-forming cells is severely impaired by MMP deficiency. This defect is coincident with signs of severe disorganization and disruption in the osteogenic periosteum. Transplantation of osteogenic cells to MMP-sufficient hosts confirmed that MMP deficiency caused an intrinsic defect of osteogenic cells that could not be rescued by an MMP-sufficient environment. The transplantation experiment also showed that the defect in osteogenesis is coupled to inability to degrade a collagenous matrix, a finding that is consistent with extensive fibrosis of the osteogenic periosteum and disruption of its highly ordered cellular architecture. The unusual finding of collagen fibrils inside osteoblasts, moreover, suggested that these cells attempted to mobilize a compensatory phagocytic pathway of collagen degradation [47]. Therefore the inability to remodel the surrounding collagenous matrix may result in disorganization of the osteoblast layer, displacement of osteoblasts, and failure to achieve a level of coordinated function required for bone formation.

Based on these observations and existed evidences, MMP is capable of cleaving extracellular matrix substrates such as collagen and fibrin [48], loss of MMP-directed proteolysis results in profound and far reaching physiological consequences. Equally significant, the phenotype illustrates the importance of collagenous stromal remodeling for development and growth, and for maintenance of the otherwise invisible functional continuity between the soft and hard tissue components of the skeleton. In conclusion, our results indicate that mesenchymal stem cells significantly enhance the efficacy of collageninduced arthritis treatment, which is superior to betamethasone treatment likely through the modulation of the expression of various cytokines.

\section{References}

1. Tse WT, Pendleton JD, Beyer WM, Egalka MC, Guinan EC (2003) Suppression of allogeneic T-cell proliferation by human marrow stromal cells: implications in transplantation. Transplantation 75: 389-397.

2. Pittenger MF, Mackay AM, Beck SC, Jaiswal RK, Douglas R, et al. (1999) Multilineage potential of adult human mesenchymal stem cells. Science 284 : 143-147.
3. Deans RJ, Moseley AB (2000) Mesenchymal stem cells: biology and potential clinical uses. Exp Hematol 28: 875-884.

4. Imanishi $\mathrm{Y}$, Saito A, Komoda H, Kitagawa-Sakakida S, Miyagawa S, et al. (2008) Allogenic mesenchymal stem cell transplantation has a therapeutic effect in acute myocardial infarction in rats. J Mol Cell Cardiol 44: 662-671.

5. van Poll D, Parekkadan B, Cho $\mathrm{CH}$, Berthiaume F, Nahmias $\mathrm{Y}$, et al. (2008) Mesenchymal stem cell-derived molecules directly modulate hepatocellular death and regeneration in vitro and in vivo. Hepatology 47: 1634-1643.

6. Qian H, Yang H, Xu W, Yan Y, Chen Q, et al. (2008) Bone marrow mesenchymal stem cells ameliorate rat acute renal failure by differentiation into renal tubular epithelial-like cells. Int J Mol Med 22: 325-332.

7. Polchert D, Sobinsky J, Douglas G, Kidd M, Moadsiri A, et al. (2008) IFNgamma activation of mesenchymal stem cells for treatment and prevention of graft versus host disease. Eur J Immunol 38: 1745-1755.

8. Iking-Konert C, Ostendorf B, Schneider M (2007) Management of early rheumatoid arthritis. Med Monatsschr Pharm 30: 94-100.

9. Saag KG, Townsend HB (2002) Glucocorticoid use in rheumatoid arthritis Benefits, mechanisms, and risks. Curr Rheumatol Reports 4: 218-225.

10. Kirwan JR (1995) The effect of glucocorticoids on joint destruction in rheumatoid arthritis. N Engl J Med 333: 142-147.

11. Labhasetwar V, Song C, Levy RJ (1997) Nanoparticle drug delivery system for restenosis. Advanced Drug Delivery Reviews 24: 63-85.

12. Gref R, Minamitake Y, Peracchia MT, Trubetskoy V, Torchilin V, et al. (1994) Biodegradable long-circulating polymeric nanospheres. Science 263: 16001603.

13. Augello A, Tasso R, Negrini SM, Cancedda R, Pennesi G (2007) Cell therapy using allogeneic bone marrow mesenchymal stem cells prevents tissue damage in collagen-induced arthritis. Arthritis Rheum 56: 1175-1186.

14. Djouad F, Fritz V, Apparailly F, Louis-Plence P, Bony C, et al. (2005) Reversa of the immunosuppressive properties of mesenchymal stem cells by tumor necrosis factor alpha in collagen-induced arthritis. Arthritis Rheum 52: 15951603.

15. Larsson E, Erlandsson Harris H, Larsson A, Månsson B, Saxne T, et al. (2003) Corticosteroid treatment of experimental arthritis retards cartilage destruction as determined by histology and serum COMP. Rheumatology (Oxford) 43: 428434

16. Maccario R, Podestà M, Moretta A, Cometa A, Comoli P, et al. (2005) Interaction of human mesenchymal stem cells with cells involved in alloantigen-specific immune response favors the differentiation of CD4+ T-cell subsets expressing a regulatory/suppressive phenotype. Haematologica 90: 516-525.

17. Crawford WH, Houge JC, Neirby DT, Di Mino A, Di Mino AA (1991) Pulsed radio frequency therapy of experimentally induced arthritis in ponies. Can $\mathrm{J}$ Vet Res 55: 76-85.

18. Abdel Aziz MT, Atta HM, Mahfouz S, Fouad HH, Roshdy NK, et al. (2007) Therapeutic potential of bone marrow-derived mesenchymal stem cells on experimental liver cirrhosis. Clin Biochem 40: 893-899.

19. Zhou K, Zhang H, Jin O, Feng X, Yao G, et al. (2008) Transplantation of human bone marrow mesenchymal stem cell ameliorates the autoimmune pathogenesis in MRL/lpr mice. Cell Mol Immunol 5: 417-424.

20. Park SH, Min DJ, Cho ML, Kim WU, Youn J, et al. (2001) Shift toward Thelper 1 cytokines by type II collagen-reactive $T$ cells in patients with rheumatoid arthritis. ArthritisRheum 44: 561-569.

21. Fox DA (1997) The role of T cells in the immunopathogenesis of rheumatoid arthritis: new perspectives. Arthritis Rheum 40: 598-609.

22. Maldonado A, Mueller YM, Thomas $P$, Bojczuk P, O'Connors C, et al. (2003) Decreased effector memory CD45RA+ CD62L- CD8+ T cells and increased central memory CD45RA- CD62L + CD8+ T cells in peripheral blood of rheumatoid arthritis patients. Arthritis Res Ther 5: R91-R96

23. Sekine T, Kato T, Masuko-Hongo K, Nakamura H, Yoshino S, et al. (1999) Type II collagen is a target antigen of clonally expanded T cells in the synovium of patients with rheumatoid arthritis. Ann Rheum Dis 58: 446-450.

24. Kim WU, Kim KJ (2005) T cell proliferative response to type II collagen in the inflammatory process and joint damage in patients with rheumatoid arthritis. $J$ Rheumatol 32: 225-230. 
Citation: El-denshary ESM, Rashed LA, Elhussiny M (2012) Immunosuppressive Effects of Mesenchymal Stem Cells versus Corticosteroid in Experimental Model of Arthritis. Clin Exp Pharmacol S5:003. doi:10.4172/2161-1459.S5-003

Page 10 of 10

25. Ganesan K, Tiwari M, Balachandran C, Manohar BM, Puvanakrishnan R (2008) Estrogen and testosterone attenuate extracellular matrix loss in collageninduced arthritis in rats. Calcif Tissue Int 83: 354-364

26. Min SY, Park KS, Cho ML, Kang JW, Cho YG, et al. (2006) Antigen-induced, tolerogenic $\mathrm{CD} 11 \mathrm{c}+, \mathrm{CD} 11 \mathrm{~b}+$ dendritic cells are abundant in Peyer's patches during the induction of oral tolerance to type II collagen and suppress experimental collagen-induced arthritis. ArthritisRheum 54: 887-898.

27. Lee DM, Weinblatt ME (2001) Rheumatoid Arthritis. Lancet 358: 903-911.

28. Silva I, Mateus M, Branco JC (2010) [Assessment of erythrocyte sedimentation rate (ESR) and C- reactive protein (CRP) on rheumatoid arthritis activity prediction]. Acta Reumatol Port 35: 456-462.

29. Sarban S, Kocyigit A, Yazar M, Isikan UE (2005) Plasma total antioxidant capacity, lipid peroxidation, and erythrocyte antioxidant enzyme activities in patients with rheumatoid arthritis and osteoarthritis. Clin Biochem 38: 981-986.

30. Staroń A, Makkosa G, Koter-Michalak M (2012) Oxidative stress in erythrocytes from patients with rheumatoid arthritis. Rheumatol Int 32: 331-334.

31. Torsteinsdóttir I, Hâkansson L, Hällgren R, Gudbjörnsson B, Arvidson NG, et al. (1999) Serum lysozyme: a potential marker of monocyte/macrophage activity in rheumatoid arthritis. Rheumatology (Oxford) 38: 1249-1254.

32. Resnitzky P, Shaft D, Yaari A, Nir E (1994) Distinct intracellular lysozyme content in normal granulocytes and monocytes: A quantitative immunoperoxidase and ultrastructural immunogold study. J Histochem Cytochem 42: 1471-1477.

33. Tseng S, Reddi AH, Di Cesare PE (2009) Cartilage oligomeric matrix protein (COMP): a biomarker of arthritis. Biomark Insights 4: 33-44.

34. Kokebie R, Aggarwal R, Lidder S, Hakimiyan AA, Rueger DC, et al. (2011) The role of synovial fluid markers of catabolism and anabolism in osteoarthritis, rheumatoid arthritis and asymptomatic organ donors. Arthritis Res Ther 13 R50.

35. Higaki M, Ishihara T, Izumo N, Takatsu M, Mizushima Y (2005) Treatment of experimental arthritis with poly(D, L-lactic/glycolic acid) nanoparticles encapsulating betamethasone sodium phosphate. Ann Rheum Dis 64: 11321136.

36. Ishihara T, Kubota T, Choi T, Higaki M (2009) Treatment of experimental arthritis with stealth-type polymeric nanoparticles encapsulating betamethasone phosphate. Journal of Pharmacology and Experimental Therapeutics 329: 412 417.
37. Ghannam S, Bouffi C, Djouad F, Jorgensen C, Noël D (2010) Immunosuppression by mesenchymal stem cells: mechanisms and clinical applications. Stem Cell Res Ther 1: 2 .

38. Zheng SG, Wang J, Horwitz DA (2008) Cutting edge: Foxp3+CD4+CD25+ regulatory $\mathrm{T}$ cells induced by $\mathrm{IL}-2$ and TGF-beta are resistant to Th17 conversion by IL-6. J Immunol 180: 7112-7116.

39. Rafei M, Hsieh J, Zehntner S, Li M, Forner K, et al. (2009) A granulocytemacrophage colony-stimulating factor and interleukin-15 fusokine induces a regulatory $B$ cell population with immune suppressive properties. Nat Med 15 1038-1045.

40. Ren G, Su J, Zhang L, Zhao X, Ling W, et al. (2009) Species variation in the mechanisms of mesenchymal stem cell-mediated immunosuppression. Stem Cells 27: 1954-1962.

41. Ståhle-Bäckdahl $M$, Sandstedt $B$, Bruce $K$, Lindahl $A$, Jiménez $M G$, et al (1997) Collagenase-3 (MMP-13) is expressed during human fetal ossification and re-expressed in postnatal bone remodeling and in rheumatoid arthritis. Lab Invest 76: 717-728.

42. Johnson LL, Dyer R, Hupe DJ (1998) Matrix metalloproteinases. Curr Opin Chem Biol 2: 466-471.

43. Gravallese EM, Harada Y, Wang JT, Gorn AH, Thornhill TS, et al. (1998) Identification of cell types responsible for bone resorption in rheumatoid arthritis and juvenile rheumatoid arthritis. Am J Pathol 152: 943-951.

44. Suzuki Y, Nishikaku F, Nakatuka M, Koga Y (1998) Osteoclast-like cells in murine collagen induced arthritis. J Rheumatol 25: 1154-1160.

45. Strongin AY, Collier I, Bannikov G, Marmer BL, Grant GA, et al. (1995) Mechanism of cell surface activation of 72-kDa type IV collagenase. Isolation of the activated form of the membrane metalloprotease. J Biol Chem 270: 5331 5338.

46. Kinoh H, Sato H, Tsunezuka Y, Takino T, Kawashima A, et al. (1996) MT-MMP the cell surface activator of proMMP-2 (pro-gelatinase A), is expressed with its substrate in mouse tissue during embryogenesis. J Cell Sci 109: 953-959.

47. Hiraoka N, Allen E, Apel IJ, Gyetko MR, Weiss SJ (1998) Matrix metalloproteinases regulate neovascularization by acting as pericellular fibrinolysins. Cell 95: 365-377.

48. Werb Z (1997) ECM and cell surface proteolysis: regulating cellular ecology Cell 91: 439-442.
This article was originally published in a special issue, Pharmacology and Toxicology for Safe and Effective Therapy handled by Editor(s). Dr. Peter R. Martin, Vanderbilt Psychiatric Hospital, USA 